(c) American Dairy Science Association, 2006.

\title{
Leukocyte Populations and mRNA Expression of Inflammatory Factors in Quarter Milk Fractions at Different Somatic Cell Score Levels in Dairy Cows
}

\author{
H. Sarikaya, G. Schlamberger, H. H. D. Meyer, and R. M. Bruckmaier ${ }^{1,2}$ \\ Physiology Weihenstephan, Technical University Munich, D-85350 Freising, Germany
}

\begin{abstract}
The effect of somatic cell count (SCC) and milk fraction on milk composition, distribution of cell populations, and mRNA expression of various inflammatory parameters was studied. Therefore, quarter milk samples were defined as cisternal (C), first $400 \mathrm{~g}$ of alveolar (A1), and remaining alveolar milk (A2) during the course of milking. Quarters were assigned to 4 groups according to their total SCC: 1 ) $<12 \times 10^{3} / \mathrm{mL}$, 2) 12 to $100 \times 10^{3} / \mathrm{mL}$, 3) 100 to $350 \times 10^{3} / \mathrm{mL}$, and 4) $>350 \times 10^{3} / \mathrm{mL}$. Milk constituents of interest were SCC, fat, protein, lactose sodium, and chloride ions as well as electrical conductivity. Cell populations were classified into lymphocytes, macrophages, and neutrophils (PMN). The mRNA expression of the inflammatory factors tumor necrosis factor- $\alpha$, interleukin- $1 \beta$, cyclooxygenase- 2 , lactoferrin, and lysozyme was measured via real-time, quantitative reverse transcription PCR. Somatic cell count decreased from highest levels in $\mathrm{C}$ to lowest levels in A1 and increased thereafter to A2 in all groups. Fat content increased from $\mathrm{C}$ to $\mathrm{A} 2$ and with increasing SCC level. Lactose decreased with increasing SCC level but remained unchanged during milking. Concentrations of sodium and chloride, and electrical conductivity increased with increasing SCC but were higher in C than in A1 and A2. Protein was not affected by milk fraction or SCC level. The distribution of leukocytes was dramatically influenced by milk fraction and SCC. Lymphocytes were the dominating cell population in group 1 , but the proportion of lymphocytes was low in groups 2,3 , and 4. Macrophage proportion was highest in group 2 and decreased in groups 3 and 4, whereas that of PMN increased from group 2 to 4 . The content of macrophages decreased during milking in all SCC groups whereas that of PMN increased. The proportion of lymphocytes was not affected by milk fraction. The mRNA expression
\end{abstract}

Received September 2, 2005.

Accepted November 28, 2005.

${ }^{1}$ Corresponding author: rupert.bruckmaier@physio.unibe.ch

${ }^{2}$ Current address: Veterinary Physiology, Vetsuisse Faculty, University of Bern, Bremgartenstr. 109a CH-3012 Bern, Switzerland. of all inflammatory factors showed an increase with increasing SCC but minor changes occurred during milking. In conclusion, milk fraction and SCC level have a crucial influence on the distribution of leukocyte populations and several milk constituents. The surprisingly high content of lymphocytes and concomitantly low mRNA expression of inflammatory factors in quarters with SCC $<12 \times 10^{3} / \mathrm{mL}$ indicates a different and possibly reduced readiness of the immune system to respond to invading pathogens.

Key words: milk fraction, leukocyte, mRNA expression

\section{INTRODUCTION}

Microbiological and SCC testing in milk are the most sensitive methods for measurement of infection of bovine mammary glands. Somatic cell count presents a fast and reliable analytical tool. It is related to the immunological status of the udder and increases in response to an inflammatory stimulus like bacterial infection (O'Brien et al., 1999; Leitner et al., 2000). Therefore, SCC is a widely used indicator for udder health and milk quality.

Somatic cell count varies somewhat according to milking frequency, lactational stage, age, and nutrition (Dohoo et al., 1984; Kelly et al., 2000). Somatic cell count measurement includes all types of cells in milk; the number and the distribution of lymphocytes, macrophages, PMNL, and epithelial cells depend on the immunological status of the mammary gland (Kehrli and Schuster, 1994; Kelly et al., 2000). In milk from healthy udders, macrophages represent the major cell fraction (Burvenich et al., 1994; Paape et al., 2002; Sarikaya et al., 2004), and release chemoattractants such as tumor necrosis factor alpha (TNF- $\alpha)$ and interleukin-1 $\beta$ (IL-1 $\beta)$ after contact with a pathogen (Hoeben et al., 2000; Wittmann et al., 2002). This stimulus causes a rapid immigration of PMNL into the milk (Jensen and Eberhardt, 1981; Sordillo and Streicher, 2002). Therefore, in mastitic milk, PMNL become the predominant cell fraction (Kehrli and Schuster, 1994; Paape et al., 2002).

In addition to the changes of SCC and cell populations based on immunological status, there are also alterations in milk constituents during the course of milking; 
that is, in different milk fractions (Ontsouka et al., 2003; Bruckmaier et al., 2004a). Because milk ejection is a continuous process during the course of milking (Bruckmaier et al., 1994), it can be hypothesized that there are also changes in cell populations in different milk fractions. Immunomediators support the defense mechanism of the mammary gland by exerting potent chemotactic effects on leukocytes; they also enhance phagocytotic activity (Persson et al., 1993; Sanchez et al., 1994). The mediators of most importance are cytokines such as TNF- $\alpha$ and IL-1 $\beta$ as well as lipid derivatives such as leukotrienes and prostaglandins. Bacteriostatic proteins such as lactoferrin (Lf) and lysozyme (Lz) have been shown to increase during mastitis (Hagiwara et al., 2003; Schmitz et al., 2004).

The present study aimed to assess the hypothesis that in different udder compartments such as the teat/cisternal area and alveolar tissue, different cell types have specific importance and are therefore present in variable distribution. Quarter milk samples were classified according to their SCC levels to investigate the influence of the immunological status on cell distribution and mRNA abundance. To achieve a detailed overview, the mRNA expression levels of various inflammatory factors in milk cells and concentration of milk constituents were studied concomitantly. Because the immunological status is considered crucial for the current SCC level, grouping of quarters was performed based on SCC without regard to the bacteriological status.

\section{MATERIALS AND METHODS}

\section{Animals and Husbandry}

In experiment 1,29 dairy cows (15 Simmental, 7 Brown Swiss, and 7 Holstein-Friesian) in their first to seventh lactations were used. Seven animals were in an early stage of lactation ( 13 to $94 \mathrm{~d}$ ), 12 were in mid lactation (107 to $198 \mathrm{~d}$ ), and 10 were in a late stage of lactation (216 to $377 \mathrm{~d}$ ).

Experiment 2 included 33 animals (8 Simmental, 20 Brown Swiss, and 5 Holstein-Friesian) in their first to fifth lactations. Nine cows were in an early stage of lactation (10 to $96 \mathrm{~d}$ ), 7 were in mid lactation (117 to $204 \mathrm{~d}$ ), and 17 were in a late lactational stage (235 to $533 \mathrm{~d}$ ).

The average milk production on the day of investigation was $23 \mathrm{~kg} / \mathrm{cow}$. Cows were kept in a loose-housing barn, and milked twice daily at 0500 and $1600 \mathrm{~h}$.

\section{Experimental Design}

Both studies included fractionized milking during routine milking times with a special quarter milking equipment. This device allowed an online separation of the whole quarter milk sample into 3 fractions: the cisternal milk (C), first $400 \mathrm{~g}$ of alveolar milk (A1), and the remaining alveolar milk (A2). To obtain a $\mathrm{C}$ fraction free of alveolar milk, milking was performed without any udder preparation to avoid milk ejection (Bruckmaier and Blum, 1996). According to Bruckmaier and Hilger (2001), no milk ejection is expected in the first $50 \mathrm{~s}$ after the start of milking. Therefore, all milk removed during the first $50 \mathrm{~s}$ was classified as $\mathrm{C}$. All collected samples were immediately stored at $4^{\circ} \mathrm{C}$ and transferred to further processing.

\section{SCC and Milk Composition}

Somatic cell counts of all milk samples in experiments 1 and 2 were measured with a DeLaval cell counter (Tumba, Sweden). The DeLaval cell counter was particularly suitable because it requires a minimum sample size of only $60 \mu \mathrm{L}$ (Sarikaya and Bruckmaier, 2005). Milk samples were assigned to 1 of 4 groups according to their total quarter SCC: 1 ) $<12 \times 10^{3} / \mathrm{mL}$, 2) 12 to 100 $\times 10^{3} / \mathrm{mL}$, 3) 100 to $350 \times 10^{3} / \mathrm{mL}$, and 4) $>350 \times 10^{3} / \mathrm{mL}$.

The milk samples of experiment 1 were analyzed for fat, protein, and lactose in every fraction by an accredited milk laboratory (Milchprüfring Bayern e.V., Wolnzach, Germany) using the MilkoScan 4500 analyzer (Foss, Hillerød, Denmark). Potentiometric measurement using ion-selective electrodes (models 9811 and 9617BN, pH/ Ise Meter 720 Aplus, Orion Research, Boston, MA) was performed directly in milk for sodium and chloride. Electrical conductivity (EC) was measured in milk using the LDM 130 electrode from WTW (Weilheim, Germany).

\section{Milk Cell Isolation}

Within 30 min after sampling, the somatic cells of each fraction were isolated for further investigations. Isolation was performed by centrifugation as described by Sarikaya et al. (2004). The cells were washed, resuspended in PBS ( $\mathrm{pH}$ 7.5), and kept on ice during all procedures.

\section{Cell Populations}

Differential cell counting in experiment 1 was performed by using light microscopy and a modified Pappenheim staining (Sarikaya et al., 2004); 200 cells were counted and the populations were calculated as percentages of the total. Leukocytes were defined as lymphocytes, macrophages, or PMNL.

\section{RNA Extraction}

Total RNA of milk cells was isolated using TriPure (Roche Diagnostics, Mannheim, Germany) according to 
Table 1. Sequence of PCR primers, accession number, and PCR product length

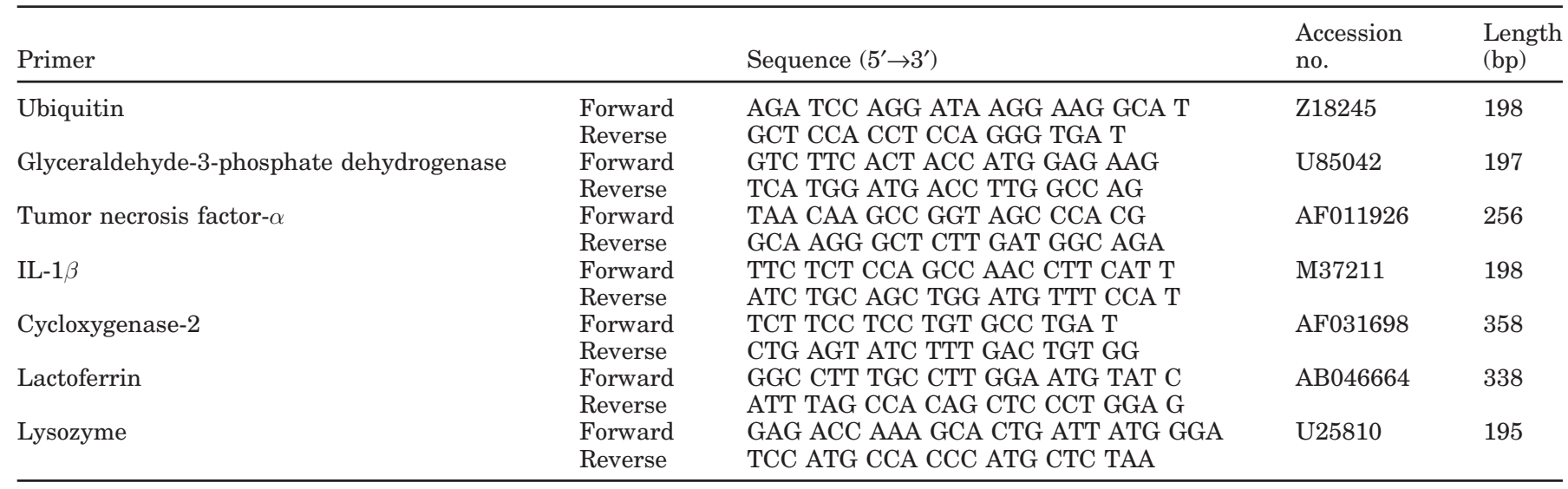

the manufacturers recommendations. To quantify the amount of total RNA, optical density was measured at 3 different dilutions at $260 \mathrm{~nm}$ and corrected by the $320 \mathrm{~nm}$ background absorption. Integrity of RNA was verified by the $\mathrm{OD}_{260 \mathrm{~nm}} / \mathrm{OD}_{280 \mathrm{~nm}}$ absorption ratio being $>1.7$.

\section{Oligonucleotide Primers}

Primers for the housekeeping and target genes were synthesized commercially (MWG Biotech, Ebersberg, Germany) using previously published bovine-specific primer sequences (Wittmann et al., 2002; Schmitz et al., 2004). Primer information is listed in Table 1.

\section{Quantification by Real-Time, Reverse Transcription-PCR}

Quantitative analysis of PCR products was carried out on the RotorGene 3000 (Corbett Research, Sydney, Australia) via one-step quantitative reverse transcription-PCR. In brief, $3.8 \mu \mathrm{L}$ of extracted mRNA solutions with a concentration of $15 \mathrm{ng} / \mu \mathrm{L}$ were used. Additional reaction components were $6.2 \mu \mathrm{L}$ of Master Mix (SuperScript III Platinum SYBR Green One-Step qRT-PCR Kit, Invitrogen, Kaulsruhe, Germany) including $5 \mu \mathrm{L}$ of $2 \times$ SYBR Green Reaction Mix, $0.2 \mu \mathrm{L}$ of SYBR Green One-Step Enzyme Mix, $0.5 \mu \mathrm{L}$ (10 p $M$ ) of forward primer, and $0.5 \mu \mathrm{L}(10 \mathrm{p} M)$ of reverse primer.

Crossing point values were achieved by RotorGene software version 5.0. A normalisation of the target genes with an endogenous standard was performed. Therefore, the expression levels of the housekeeping genes glyceraldehyde-3-phosphate dehydrogenase and ubiquitin were measured. The relative mRNA levels were calculated by normalization of the crossing point of the target gene to the mean crossing point of the 2 housekeeping genes.

\section{Statistical Analyses}

Data are presented as means \pm standard error of means (SEM). Differences between itemized fractions and SCC groups were tested for significance $(P<0.05)$ by ANOVA using the MIXED models procedure of SAS (SAS Institute, Inc., Cary, NC). The MIXED model included the animal and the milk fraction as class variables. The animal was the repeated term during the course of milking. The compound-symmetry matrix structure was used. Statistical significance between fractions was tested by least significance difference test.

\section{RESULTS}

\section{Milk Cells}

All investigated milk samples were assigned to 1 of 4 groups according to their total quarter milk SCC. Mean SCC in groups $1,2,3$, and 4 were $9 \pm 1,39 \pm 10,215 \pm$ 27 , and $2,460 \pm 1,172 \times 10^{3} / \mathrm{mL}$, respectively, in experiment 1 , and $9 \pm 2,48 \pm 6,186 \pm 26$, and 1,046 $\pm 442 \times$ $10^{3} / \mathrm{mL}$, respectively, in experiment 2 . Somatic cell count decreased in all groups from $\mathrm{C}$ to $\mathrm{A} 1$ and increased in A2. Somatic cell counts of all quarters were $1.2 \times 10^{6} \pm$ $5.4 \times 10^{5}$ cells $/ \mathrm{mL}$ in $\mathrm{C}, 4.9 \times 10^{5} \pm 2.6 \times 10^{5}$ cells $/ \mathrm{mL}$ in $\mathrm{A} 1$, and $9.3 \times 10^{5} \pm 5.2 \times 10^{5}$ cells $/ \mathrm{mL}$ in A2. The SCC of all fractions in groups $1,2,3$, and 4 are shown in Table 2.

\section{Milk Constituents}

As shown in Table 2, the concentration of fat increased $(P<0.05)$ from $\mathrm{C}$ to $\mathrm{A} 1$ and A2 during milking for all quarter milk samples. This difference could be seen in SCC groups 1 to 4 from $\mathrm{C}$ to $\mathrm{A} 1$, and from $\mathrm{C}$ to $\mathrm{A} 2$. An increase $(P<0.05)$ from A1 to A2 was only observed in groups 1,2 , and 4 . The concentration of protein showed 
Table 2. Composition of quarter milk samples (QMS) within different milk fractions and SCC groups

\begin{tabular}{|c|c|c|c|c|c|c|}
\hline \multirow[b]{2}{*}{ Composition } & \multirow[b]{2}{*}{ Fraction $^{1}$} & \multicolumn{4}{|c|}{ SCC group ${ }^{2}$} & \multirow{2}{*}{$\begin{array}{l}\text { All QMS } \\
(\text { mean })^{3}\end{array}$} \\
\hline & & $1(\mathrm{n}=6)$ & $2(\mathrm{n}=8)$ & $3(\mathrm{n}=7)$ & $4(\mathrm{n}=8)$ & \\
\hline \multirow[t]{3}{*}{$\mathrm{SCC}, \log 10 / \mathrm{mL}$} & $\mathrm{C}$ & $3.84 \pm 0.13$ & $4.69 \pm 0.15$ & $5.32 \pm 0.22$ & $6.15 \pm 0.24$ & $5.16 \pm 0.18$ \\
\hline & $\mathrm{A} 1$ & $3.43 \pm 0.04$ & $4.24 \pm 0.12$ & $4.91 \pm 0.13$ & $5.77 \pm 0.24$ & $4.75 \pm 0.17$ \\
\hline & $\mathrm{A} 2$ & $4.01 \pm 0.08$ & $4.51 \pm 0.10$ & $5.34 \pm 0.03$ & $6.15 \pm 0.18$ & $5.14 \pm 0.16$ \\
\hline \multirow[t]{3}{*}{ Fat, $\%$} & $\mathrm{C}$ & $1.3 \pm 0.2^{\mathrm{cB}}$ & $1.4 \pm 0.3^{\mathrm{cB}}$ & $2.2 \pm 0.4^{\mathrm{bAB}}$ & $2.4 \pm 0.4^{\mathrm{cA}}$ & $1.9 \pm 02^{\mathrm{c}}$ \\
\hline & $\mathrm{A} 1$ & $2.2 \pm 0.3^{\mathrm{bB}}$ & $2.1 \pm 0.3^{\mathrm{bB}}$ & $2.8 \pm 0.3^{\mathrm{bAB}}$ & $3.0 \pm 0.4^{\mathrm{bA}}$ & $2.6 \pm 0.2^{\mathrm{b}}$ \\
\hline & $\mathrm{A} 2$ & $4.7 \pm 0.6^{\mathrm{a}}$ & $4.4 \pm 0.3^{\mathrm{a}}$ & $4.7 \pm 0.1^{\mathrm{a}}$ & $4.7 \pm 0.3^{\mathrm{a}}$ & $4.6 \pm 0.1^{\mathrm{a}}$ \\
\hline \multirow[t]{3}{*}{ Protein, \% } & $\mathrm{C}$ & $3.2 \pm 0.1^{\mathrm{B}}$ & $3.4 \pm 0.1^{\mathrm{AB}}$ & $3.4 \pm 0.1^{\mathrm{AB}}$ & $3.7 \pm 0.1^{\mathrm{A}}$ & $3.5 \pm 0.1$ \\
\hline & $\mathrm{A} 1$ & $3.2 \pm 0.1^{\mathrm{B}}$ & $3.5 \pm 0.1^{\mathrm{B}}$ & $3.4 \pm 0.1^{\mathrm{B}}$ & $3.8 \pm 0.1^{\mathrm{A}}$ & $3.5 \pm 0.1$ \\
\hline & $\mathrm{A} 2$ & $3.1 \pm 0.1^{\mathrm{B}}$ & $3.4 \pm 0.1^{\mathrm{B}}$ & $3.4 \pm 0.1^{\mathrm{B}}$ & $3.8 \pm 0.1^{\mathrm{A}}$ & $3.5 \pm 0.1$ \\
\hline \multirow[t]{3}{*}{ Lactose, $\%$} & $\mathrm{C}$ & $5.0 \pm 0.1^{\mathrm{A}}$ & $4.8 \pm 0.2^{\mathrm{AB}}$ & $4.6 \pm 0.1^{\mathrm{BC}}$ & $4.4 \pm 0.2^{\mathrm{C}}$ & $4.7 \pm 0.1^{\mathrm{b}}$ \\
\hline & $\mathrm{A} 1$ & $5.0 \pm 0.1^{\mathrm{A}}$ & $5.0 \pm 0.1^{\mathrm{A}}$ & $4.9 \pm 0.1^{\mathrm{AB}}$ & $4.7 \pm 0.1^{\mathrm{B}}$ & $4.9 \pm 0.1^{\mathrm{a}}$ \\
\hline & $\mathrm{A} 2$ & $5.0 \pm 0.1^{\mathrm{A}}$ & $4.9 \pm 0.1^{\mathrm{A}}$ & $4.8 \pm 0.1^{\mathrm{AB}}$ & $4.5 \pm 0.1^{\mathrm{B}}$ & $4.8 \pm 0.1^{\mathrm{a}}$ \\
\hline \multirow[t]{3}{*}{ Sodium, mmol/L } & $\mathrm{C}$ & $9.6 \pm 3.1^{\mathrm{C}}$ & $21.8 \pm 6.7^{\mathrm{aB}}$ & $18.3 \pm 2.1^{\mathrm{aBC}}$ & $37.2 \pm 7.0^{\mathrm{aA}}$ & $23.7 \pm 3.3^{\mathrm{a}}$ \\
\hline & $\mathrm{A} 1$ & $7.6 \pm 1.9$ & $13.7 \pm 4.2^{\mathrm{b}}$ & $12.2 \pm 1.7^{\mathrm{b}}$ & $20.2 \pm 3.5^{\mathrm{b}}$ & $14.3 \pm 1.8^{\mathrm{b}}$ \\
\hline & $\mathrm{A} 2$ & $7.0 \pm 2.2^{\mathrm{B}}$ & $11.5 \pm 2.2^{\mathrm{bB}}$ & $11.8 \pm 1.3^{\mathrm{bB}}$ & $23.5 \pm 5.1^{\mathrm{bA}}$ & $14.5 \pm 2.0^{\mathrm{b}}$ \\
\hline \multirow[t]{3}{*}{ Chloride, $\mathrm{mmol} / \mathrm{L}$} & $\mathrm{C}$ & $37.4 \pm 4.8^{\mathrm{BC}}$ & $56.5 \pm 10.5^{\mathrm{aB}}$ & $41.3 \pm 3.2^{\mathrm{aB}}$ & $85.8 \pm 25.2^{\mathrm{aA}}$ & $58.4 \pm 8.5^{\mathrm{a}}$ \\
\hline & $\mathrm{A} 1$ & $32.9 \pm 3.7$ & $37.5 \pm 4.0^{\mathrm{b}}$ & $30.2 \pm 1.8^{\mathrm{b}}$ & $47.9 \pm 8.5^{\mathrm{b}}$ & $38.0 \pm 3.0^{\mathrm{b}}$ \\
\hline & $\mathrm{A} 2$ & $34.3 \pm 4.4^{\mathrm{B}}$ & $38.6 \pm 3.7^{\mathrm{bAB}}$ & $32.4 \pm 2.2^{\mathrm{abAB}}$ & $60.2 \pm 12.3^{\mathrm{ba}}$ & $42.8 \pm 4.3^{\mathrm{b}}$ \\
\hline \multirow[t]{3}{*}{ Electrical conductivity, $\mathrm{mS} / \mathrm{cm}$} & $\mathrm{C}$ & $41.6 \pm 0.4^{\mathrm{aB}}$ & $46.9 \pm 2.2^{\mathrm{aB}}$ & $46.9 \pm 0.9^{\mathrm{aB}}$ & $53.7 \pm 4.1^{\mathrm{aA}}$ & $48.1 \pm 1.5^{\mathrm{a}}$ \\
\hline & $\mathrm{A} 1$ & $40.4 \pm 0.5^{\mathrm{b}}$ & $41.9 \pm 0.8^{\mathrm{b}}$ & $42.7 \pm 1.7^{\mathrm{b}}$ & $43.8 \pm 0.9^{\mathrm{b}}$ & $42.5 \pm 0.6^{\mathrm{b}}$ \\
\hline & $\mathrm{A} 2$ & $35.7 \pm 3.3^{\mathrm{bC}}$ & $40.4 \pm 0.6^{\mathrm{bBc}}$ & $41.7 \pm 1.0^{\mathrm{bAB}}$ & $45.2 \pm 1.6^{\mathrm{bA}}$ & $41.5 \pm 0.9^{b}$ \\
\hline
\end{tabular}

${ }^{\mathrm{a}, \mathrm{b}}$ Means without common index within SCC group and composition parameter differ significantly $(P<0.05)$ between milk fractions.

${ }^{\mathrm{A}-\mathrm{C}}$ Means without common index within milk fraction and composition parameter differ significantly $(P<0.05)$ between SCC groups.

${ }^{1}$ Fractions: $\mathrm{C}=$ cisternal; $\mathrm{A} 1$ = first $400 \mathrm{~g}$ of alveolar milk; $\mathrm{A} 2$ = remainder of alveolar milk.

${ }^{2} \mathrm{SCC}$ groups: $1=<12 \times 10^{3} / \mathrm{mL} ; 2=12$ to $100 \times 10^{3} / \mathrm{mL} ; 3=100$ to $350 \times 10^{3} / \mathrm{mL}$; and $4=>350 \times 10^{3} / \mathrm{mL}$.

${ }^{3}$ Mean of all QMS.

minor changes during milking in all SCC groups. Within fraction in different SCC groups, the protein content was always lowest in group 1 . It increased $(P<0.05)$ for $\mathrm{C}$ between groups 1 and 4 , and for $\mathrm{A} 1$ and $\mathrm{A} 2$ among groups $1,2,3$, and 4 . Lactose levels increased $(P<0.05)$ from $\mathrm{C}$ to $\mathrm{A} 1$ and decreased numerically from $\mathrm{A} 1$ to A2. Group 1 maintained constant lactose contents throughout milking and showed the highest concentrations compared with SCC groups 2, 3, and 4.

\section{Milk Electrolytes and EC}

As demonstrated in Table 2, sodium concentrations decreased $(P<0.05)$ from $\mathrm{C}$ to fractions $\mathrm{A} 1$ and $\mathrm{A} 2$. The changes $(P<0.05)$ between the SCC groups showed lower sodium levels in $\mathrm{C}$ and $\mathrm{A}$ fractions in groups 1,2 , and 3 compared with group 4 . The content of chloride presented the same trends and significances as sodium during milking for all groups. Group 4 had $(P<0.05)$ higher levels in fractions $\mathrm{C}$ and $\mathrm{A} 2$ compared with groups 1,2 , and 3. Electrical conductivity decreased $(P<0.05)$ from the cisternal to alveolar fractions. Likewise, SCC group 4 showed greater EC $(P<0.05)$ compared with groups 1,2 , and 3 .

\section{Cell Populations}

The lymphocytes comprised the predominant cell population in SCC group 1, whereas the content of macro- phages and PMNL was low. In contrast, the proportion of lymphocytes was low $(P<0.05)$ in all fractions of groups 2, 3, and 4. Macrophages were highest in group 2 , and decreased $(P<0.05)$ in groups 1,3 , and 4 . In contrast, the ratio of PMNL was low in group 2 and was elevated $(P<0.05)$ with increasing SCC in groups 3 and 4.

The course of milking showed minor changes in lymphocyte concentrations in all SCC groups. The content of macrophages decreased $(P<0.05)$ during the course of milking in all groups, showing highest levels in the $\mathrm{C}$ fraction of group 2 . An increase $(P<0.05)$ in the proportion of PMNL during the course of milking was observed in all groups. The cell distributions of the 4 groups are presented in Figure 1.

\section{mRNA Expression of Inflammatory Factors}

The cytokines TNF- $\alpha$ and IL- $1 \beta$ showed higher mRNA expression levels $(P<0.05)$ with increasing SCC, except in groups 2 and 3, which showed similar values (Figure 2). Similar to TNF- $\alpha$, the expression of cyclooxygenase2 (COX-2) mRNA increased $(P<0.05)$ to its highest levels in SCC group 4; expression of Lf also increased from group 1 to 4 . Group 1 could not be analyzed for $\mathrm{Lz}$ expression because of technical reasons. Therefore, only SCC groups 2, 3, and 4 were investigated for this gene. The effect of SCC on Lz gene expression was positively 

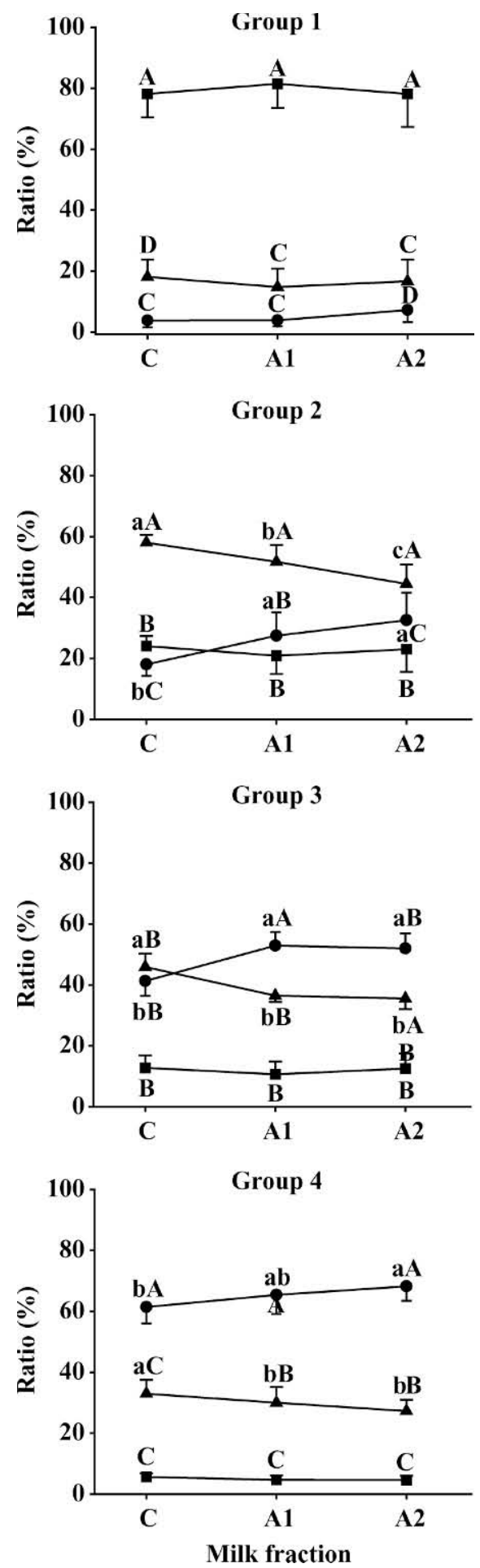

Figure 1. Distribution of cell populations $(=\mathrm{PMNL}, \boldsymbol{\square}=$ lymphocytes, $\boldsymbol{\Delta}=$ macrophages $)$ subject to milk fractions $(\mathrm{C}=$ cisternal; $\mathrm{A} 1=$ first $400 \mathrm{~g}$ of alveolar milk; A2 = remaining alveolar milk) and SCC groups 1 to $4\left(1=<12 \times 10^{3} / \mathrm{mL} ; 2=12\right.$ to $100 \times 10^{3} / \mathrm{mL} ; 3=100$ to $350 \times 10^{3} / \mathrm{mL}$; and $\left.4=>350 \times 10^{3} / \mathrm{mL}\right) .{ }^{\mathrm{a}-c}$ Means without common index within SCC group and cell population differ significantly $(P<$ 0.05 ) between milk fractions; ${ }^{\mathrm{A}-\mathrm{C}}$ Means without common index within milk fraction and cell population differ significantly $(P<0.05)$ between SCC groups. correlated; that is, higher SCC led to higher mRNA expression $(P<0.05)$.

There were no significant differences in expression of cytokine (TNF- $\alpha$ and IL-1 $\beta$ ) mRNA during the course of milking among the 4 SCC groups (Figure 2). Only SCC group 3 differed throughout milking by an increased expression level $(P<0.05)$ in fraction A2. Expression of COX-2, Lf, and Lz showed minor changes during milking. The mRNA expression levels for COX-2, Lf, and Lz are shown in Table 3.

\section{DISCUSSION}

Our results demonstrate changes in milk composition, cell population, and mRNA expression of different inflammatory parameters based on 2 important factorsSCC and milk fraction. The collected milk fractions of a single quarter were defined as cisternal, first $400 \mathrm{~g}$ of alveolar milk, and remaining alveolar milk.

All investigated milk fractions of each quarter were assigned to groups (1 to 4) according to their total quarter SCC. In the present study, SCC in C and A2 fractions were significantly higher than SCC in the A1 fraction. This result agrees with previous findings (Woolford et al., 1998; Ontsouka et al., 2003). It shows the importance of defining the milk fraction used if SCC is used for udder health monitoring and milk quality.

The content of fat increased significantly during the course of milking as well as with elevated SCC. The change throughout the fractions could be explained by the lower density of the fat globules and the ascending force in the udder. Furthermore, a possible adhesion of the globule membranes to the alveolar lumina could support this phenomenon. Therefore, fractions with the highest fat content are removed at the end of milking. The increasing fat content in correlation with the increasing SCC was remarkable in fractions $\mathrm{C}$ and $\mathrm{A} 1$ of all 4 SCC groups. This elevated fat content could be a consequence of reduced lactose synthesis. Lactose concentrations show the opposite tendency to fat with increasing SCC (Bruckmaier et al., 2004a). Because lactose defines the milk volume, the slight fat concentration change could be a secondary effect. The course of milking showed minor changes to lactose concentrations in each SCC group.

The concentration of sodium and chloride must be considered in context with lactose, because the combination of these parameters are responsible for the osmolar equilibrium. The contents of sodium and chloride showed minor changes between the SCC groups 1,2 and 3, and a significant increase in group 4 , which presents a distinct increased level of SCC. This might be explained by the circumstance that only during high leukocyte diapedesis are the tight junctions leaky enough (Nguyen and Nev- 
TNF- $\alpha$

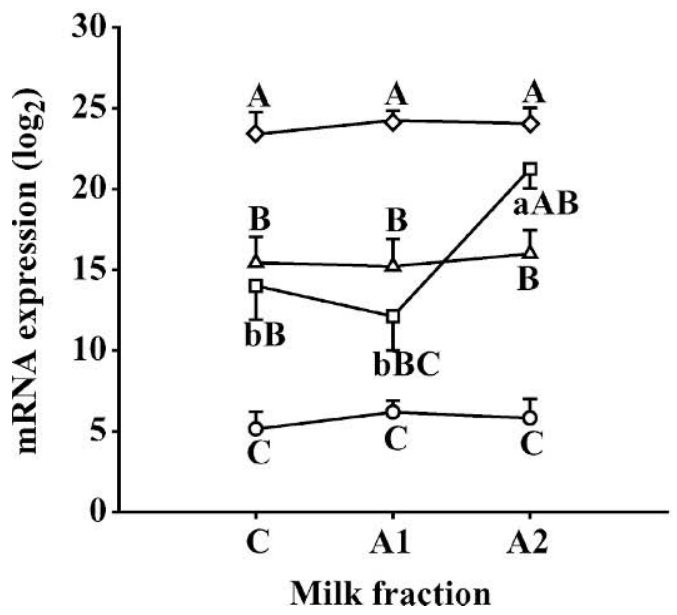

IL-1 $\beta$

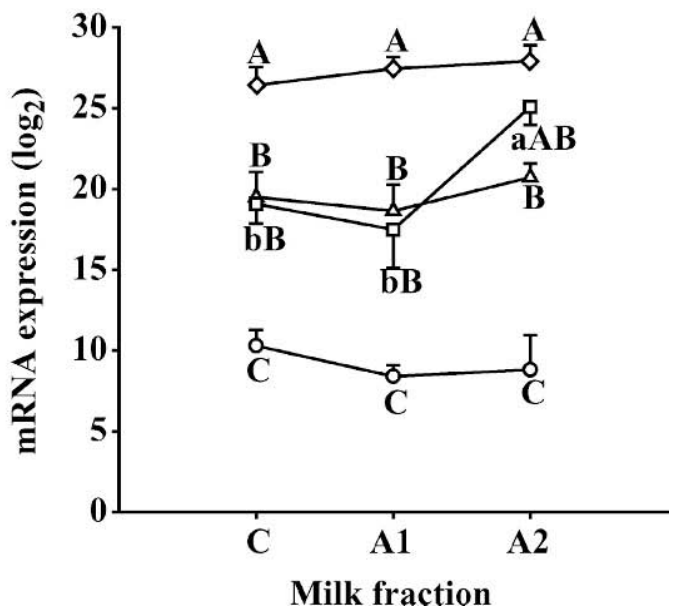

Figure 2. Relative mRNA expression levels of tumor necrosis factor- $\alpha$ and IL- $1 \beta$ in milk fractions $(\mathrm{C}=$ cisternal; A1 = first $400 \mathrm{~g}$ of alveolar milk; A2 = remaining alveolar milk) in the different SCC groups $\left(\bigcirc=\right.$ group $1:<12 \times 10^{3} / \mathrm{mL} ; \Delta=$ group $2: 12$ to $100 \times 10^{3} / \mathrm{mL} ; \square=$ group 3: 100 to $350 \times 10^{3} / \mathrm{mL} ; \diamond=$ group 4: $\left.>350 \times 10^{3} / \mathrm{mL}\right) .{ }^{\mathrm{a}, \mathrm{b}}$ Means without common index within group and target gene differ significantly $(P<0.05)$ between milk fractions; ${ }^{\mathrm{A}-\mathrm{C}}$ Means without common index within milk fraction and target gene differ significantly $(P<0.05)$ between groups.

ille, 1998; Bruckmaier et al., 2004b) to permit elevated movement of ions from blood into milk. Within a fraction, only the electrolytes in cisternal milk showed a positive correlation with SCC. After milk ejection, the sensitivity of ion measurements was reduced due to the mixture of alveolar and cisternal milk (Bruckmaier et al., 2004b). This resulted in a significant decrease of sodium and chloride during the course of milking in all 4 SCC groups. Electrical conductivity is determined by the ions dissolved in milk (mainly sodium and chloride). Therefore, EC follows the same trends as the electrolytes. The decline of EC in successive milk fractions can be affected by the increase of fat at the end of milking because fat modulates the EC measurement (Woolford et al., 1998).

The distribution of cell populations showed a dependency on the SCC as well as on the milk fraction. Macrophages were the predominant cell type in group 2 and decreased with elevating SCC. It is generally assumed that macrophages present the major cell fraction in healthy quarters (Lee et al., 1980; Paape et al., 2002). The content of macrophages was always highest in the $\mathrm{C}$ fraction, and thus decreased during milking. Because this fraction is located at the main point of entry of pathogens (the teat; Sordillo and Streicher, 2002), macrophages can react first after contact with pathogens. They initiate the inflammatory response necessary to eliminate invading pathogens by releasing chemoattractants. These chemoattractants cause a rapid influx of PMNL into the milk. Therefore, the PMNL became the major cell fraction with elevated SCC. This is the most effective mechanism against invading pathogens (Bur- venich et al., 2003; Paape et al., 2003) because these 2 cell populations represent the phagocytic cells of the mammary gland. The lymphocytes comprised only a small percentage of the cells in SCC groups 2, 3, and 4, and decreased with elevated SCC. Most surprisingly, lymphocytes were the predominant cell type in SCC group 1 comprising up to $80 \%$ of the total. The ratio of lymphocytes did not change during milking. Lymphocytes present the specific immunity of the mammary gland (Taylor et al., 1997). It is suggested that this cell fraction does not play a major role in infections of the mammary gland or that they operate in the mammary tissue rather than in milk (Riollet et al., 2001). The defense mechanism is mainly related to the innate immunity mediated by macrophages and PMNL. Furthermore, very low SCC could be associated with a higher risk of a severe infection with pathogens (Sol et al., 2000; Suriyasathaporn et al., 2000). The surprisingly low content of macrophages and PMNL and the high content of lymphocytes in quarters with SCC $<12 \times 10^{3} / \mathrm{mL}$ might cause a reduced immune response to invading pathogens. This is supported by previous investigations indicating that a very low SCC increased the risk of establishing infection with a major udder pathogen (Schukken et al., 1989; Schukken et al., 1999).

During mammary infection, nonspecific responses are the predominant defenses. For our investigations, 5 soluble immunologically important factors that are known to be involved in the natural defense mechanisms of the mammary gland against invading pathogens were selected (Schmitz et al., 2004; Prgomet et al., 2005; Ka- 
Table 3. Relative mRNA expression of cyclooxygenase-2, lactoferrin, and lysozyme within different milk fractions and SCC groups

\begin{tabular}{llllll}
\hline \multirow{2}{*}{$\begin{array}{l}\text { mRNA } \\
\text { expression }\left(\log _{2}\right)\end{array}$} & & \multicolumn{4}{c}{ SCC group $^{2}$} \\
\cline { 3 - 6 } Fraction & & $1(\mathrm{n}=4)$ & $2(\mathrm{n}=15)$ & $3(\mathrm{n}=6)$ & $4(\mathrm{n}=8)$ \\
\hline Cycloxygenase-2 & $\mathrm{C}$ & $11.4 \pm 5.2^{\mathrm{B}}$ & $12.8 \pm 1.5^{\mathrm{B}}$ & $11.4 \pm 2.3^{\mathrm{bB}}$ & $20.7 \pm 1.3^{\mathrm{A}}$ \\
& $\mathrm{A} 1$ & $6.5 \pm 3.6^{\mathrm{C}}$ & $12.5 \pm 1.6^{\mathrm{B}}$ & $8.8 \pm 2.5^{\mathrm{bBC}}$ & $22.5 \pm 0.7^{\mathrm{A}}$ \\
& $\mathrm{A} 2$ & $5.5 \pm 2.0^{\mathrm{C}}$ & $14.4 \pm 1.3^{\mathrm{B}}$ & $21.7 \pm 1.6^{\mathrm{aA}}$ & $21.9 \pm 1.6^{\mathrm{A}}$ \\
Lactoferrin & $\mathrm{C}$ & $0.8 \pm 0.7^{\mathrm{C}}$ & $16.3 \pm 1.6^{\mathrm{AB}}$ & $13.2 \pm 1.6^{\mathrm{ab}}$ & $20.4 \pm 0.9^{\mathrm{A}}$ \\
& $\mathrm{A} 1$ & $8.0 \pm 4.4^{\mathrm{C}}$ & $16.4 \pm 1.8^{\mathrm{B}}$ & $8.9 \pm 3.2^{\mathrm{bC}}$ & $22.5 \pm 0.5^{\mathrm{A}}$ \\
& $\mathrm{A} 2$ & $7.0 \pm 5.8^{\mathrm{C}}$ & $16.7 \pm 1.2^{\mathrm{B}}$ & $19.2 \pm 2.1^{\mathrm{aAB}}$ & $21.7 \pm 1.5^{\mathrm{A}}$ \\
Lysozyme & $\mathrm{C}$ & $\mathrm{ND}^{3}$ & $18.0 \pm 1.3^{\mathrm{B}}$ & $18.5 \pm 2.7^{\mathrm{aB}}$ & $24.4 \pm 1.0^{\mathrm{A}}$ \\
& $\mathrm{A} 1$ & $\mathrm{ND}$ & $16.7 \pm 1.6^{\mathrm{B}}$ & $12.3 \pm 3.1^{\mathrm{bB}}$ & $24.2 \pm 0.6^{\mathrm{A}}$ \\
& $\mathrm{A} 2$ & $\mathrm{ND}$ & $18.4 \pm 1.0^{\mathrm{B}}$ & $23.1 \pm 0.9^{\mathrm{aAB}}$ & $24.3 \pm 0.9^{\mathrm{A}}$ \\
\hline
\end{tabular}

\footnotetext{
${ }^{\mathrm{a}, \mathrm{b}}$ Means without common index within SCC group and target gene differ significantly $(P<0.05)$ between milk fractions.

${ }^{\mathrm{A}-\mathrm{C}}$ Means without common index within milk fraction and target gene differ significantly $(P<0.05)$ between SCC groups.

${ }^{1}$ Fractions: $\mathrm{C}=$ cisternal; $\mathrm{A} 1$ = first $400 \mathrm{~g}$ of alveolar milk; $\mathrm{A} 2$ = remainder of alveolar milk.

${ }^{2}$ SCC groups: $1=<12 \times 10^{3} / \mathrm{mL} ; 2=12$ to $100 \times 10^{3} / \mathrm{mL} ; 3=100$ to $350 \times 10^{3} / \mathrm{mL}$; and $4=>350 \times 10^{3} / \mathrm{mL}$.

${ }^{3} \mathrm{ND}=$ Not done (due to technical reasons).
}

wai et al., 1999). These factors were investigated during milking and dependent on SCC. Tumor necrosis factor$\alpha$ and IL- $1 \beta$ are important proinflammatory cytokines, and therefore, play a major role in the defense against mastitis (Blum et al., 2000; Riollet et al., 2000). The impact of TNF- $\alpha$ as one of the cytokines mediating the acute phase response was demonstrated because an increase of SCC occurred concomitantly with the rise of TNF- $\alpha$ mRNA expression (Figure 2); IL-1 $\beta$ showed the same pattern. It is known that these 2 cytokines stimulate IL-8 secretion (Persson et al., 1993), which is an important mediator of PMNL migration. The influx of PMNL into the mammary gland affects the progress of the infection. The course of milking affected mRNA expression marginally.

Compared with TNF- $\alpha$ and IL-1 $\beta$, an increase of Lf mRNA expression was detected with increasing SCC levels. Lactoferrin is known to increase in bovine milk during clinical mastitis (Kawai et al., 1999), and is mainly produced within the immune cells by stimulated PMNL (Prgomet et al., 2005). A significant increase of Lz mRNA expression was also obvious, with peak values in SCC group 4. These numerically increasing expression levels of Lz with SCC level indicate a possible relevance of $\mathrm{Lz}$ in the mammary gland immune defense due to its bacteriostatic effects on udder pathogens (Carlsson et al., 1989). Increased synthesis of prostaglandins and leukotrienes with increasing SCC was shown based on the increase of COX-2 mRNA expression from SCC groups 1 to 4 .

The results indicate that most of the factors investigated show significantly higher expression levels with increasing SCC. The higher levels of mRNA expressions occurred without any experimental induction of mastitis; for example, with LPS injection (Schmitz et al., 2004). This means that natural stimuli like pathogens cause the effect of an upregulation of all inflammatory factors. Changes in mRNA expression of the housekeeping genes ubiquitin and glyceraldehyde-3-phosphate dehydrogenase did not occur. Thus, the changes of mRNA represent specific responses of the mammary gland to certain stimuli that correlate with increasing SCC levels.

\section{CONCLUSIONS}

The milk fraction during the course of milking and SCC level have a crucial influence on the distribution of leukocyte populations as well as on the composition of milk. The surprisingly low content of macrophages and PMNL and concomitantly low mRNA expression of inflammatory factors in quarters with SCC $<12 \times 10^{3} / \mathrm{mL}$ indicates a different and possibly reduced readiness of the immune system to respond to invading pathogens. In contrast, the increased percentage of macrophages and PMNL in quarters with higher SCC is also reflected by high cytokine mRNA expression. The importance of somatic cells for mammary gland defense is well known and does not need to be emphasized. The results of this work suggest that not only is the total number of immune cells important in mounting an immune response-the cell type, subtype, their products, and activities may affect the progress of the infection.

\section{REFERENCES}

Blum, J. W., H. Dosogne, D. Hoeben, F. Vangroenweghe, H. M. Hammon, R. M. Bruckmaier, and C. Burvenich. 2000. Tumor necrosis factor- $\alpha$ and nitrite/nitrate responses during acute mastitis induced by Escherichia coli infection and endotoxin in dairy cows. Domest. Anim. Endocrinol. 19:223-235. 
Bruckmaier, R. M., and J. W. Blum. 1996. Simultaneous recording of oxytocin release, milk ejection and milk flow during milking of dairy cows with and without prestimulation. J. Dairy Res. 63:201-208.

Bruckmaier, R. M., and M. Hilger. 2001. Milk ejection in dairy cows at different degrees of udder filling. J. Dairy Res. 68:369-376.

Bruckmaier, R. M., C. E. Ontsouka, and J. W. Blum. 2004a. Fractionized milk composition in dairy cows with subclinical mastitis. Vet. Med. Czech 49:283-290.

Bruckmaier, R. M., D. Schams, and J. W. Blum. 1994. Continuously elevated concentrations of oxytocin during milking are necessary for complete milk removal in dairy cows. J. Dairy Res. 61:323-334.

Bruckmaier, R. M., D. Weiss, M. Wiedemann, S. Schmitz, and G. Wendl. 2004b. Changes of physicochemical indicators during mastitis and the effects of milk ejection on their sensitivity. J. Dairy Res. 71:316-321.

Burvenich, C. V., V. Merris, J. Mehrzad, A. Diez-Fraile, and L. Duchateau. 2003. Severity of $E$. coli mastitis is mainly determined by cow factors. Vet. Res. 34:521-562.

Burvenich, C. V., M. J. Paape, A. W. Hill, A. J. Guidry, R. H. Miller, R. Heyneman, W. D. Kremer, and A. Brand. 1994. Role of the neutrophil leucocyte in the local and systemic reactions during experimentally induced $E$. coli mastitis in cows immediately after calving. Vet. Q. 16:45-50.

Carlsson, A., L. Björck, and K. Persson. 1989. Lactoferrin and lysozyme in milk during acute mastitis and their inhibitory effect in Delvotest P. J. Dairy Sci. 72:3166-3175.

Dohoo, I. R., A. H. Meek, and S. W. Martin. 1984. Somatic cell counts in bovine milk: Relationships to production and clinical episodes of mastitis. Can. J. Comp. Med. 48:130-135.

Hagiwara, S., K. Kaeai, A. Anri, and H. Nagahata. 2003. Lactoferrin concentration in milk from normal and subclinical mastitic cows. J. Vet. Med. Sci. 65:319-323.

Hoeben, D., C. Burvenich, E. Trevisi, G. Bertoni, J. Hamann, R. M. Bruckmaier, and J. W. Blum. 2000. Role of endotoxin and TNF$\alpha$ in the pathogenesis of experimentally induced coliform mastitis in periparturient cows. J. Dairy Res. 67:503-514.

Jensen, D. L., and R. J. Eberhardt. 1981. Total and differential cell counts in secretion of the nonlactating bovine mammary gland. Am. J. Vet. Res. 42:743-747.

Kawai, K., S. Hagiwara, A. Anri, and H. Nagahata. 1999. Lactoferrin concentration in milk of bovine clinical mastitis. Vet. Res. Commun. 23:391-398.

Kehrli, E. M., and D. E. Shuster. 1994. Factors affecting milk somatic cells and their role in health of the bovine mammary gland. J. Dairy Sci. 77:619-627.

Kelly, A. L., D. Tiernan, C. O'Sullivan, and P. Joyce. 2000. Correlation between bovine milk somatic cell count and polymorphonuclear leukocyte level for samples of bulk milk and milk from individual cows. J. Dairy Sci. 83:300-304.

Lee, C. S., F. B. P. Wooding, and P. Kemp. 1980. Identification, properties, and differential counts of cell populations using electron microscopy of dry cows secretions, colostrum and milk from normal cows. J. Dairy Res. 47:39-50.

Leitner, G., E. Shoshani, O. Krifucks, M. Chaffer, and A. Saran. 2000. Milk leukocyte population patterns in bovine udder infection of different aetiology. J. Vet. Med. Ser. B 47:581-589.

Nguyen, D. A., and M. C. Neville. 1998. Tight junction regulation in the mammary gland. J. Mammary Gland Biol. Neoplasia 3:233-246.

O’Brien, B., C. Fitzpatrick, W. J. Meaney, and P. Joyce. 1999. Relationship between somatic cell count and neutrophils in milk. Irish J. Agric. Food Res. 38:288-296.

Ontsouka, C. E., R. M. Bruckmaier, and J. W. Blum. 2003. Fractionized milk composition during removal of colostrum and mature milk. J. Dairy Sci. 86:2005-2011.
Paape, M. J., J. Mehrzad, X. Zhao, J. Detilleux, and C. Burvenich. 2002. Defense of the bovine mammary gland by polymorphonuclear neutrophil leukocytes. J. Mammary Gland Biol. Neoplasia 7:109-121.

Paape, M. J., D. D. Bannermann, X. Zhao, and J. W. Lee. 2003. The bovine neutrophil: Structure and function in blood and milk. Vet. Res. 34:597-627.

Persson, K., I. Larsson, and C. Hallén Sandgren. 1993. Effects of certain inflammatory mediators in bovine neutrophil migration in vivo and in vitro. Vet. Immunol. Immunopathol. 37:99-112.

Prgomet, C., H. Sarikaya, R. M. Bruckmaier, and M. W. Pfaffl. 2005. Short term effects on pro-inflammatory cytokine, lactoferrin, and CD14 mRNA expression levels in bovine immuno-separated milk and blood cells treated by LPS. J. Vet. Med. A 52:317-324.

Riollet, C., P. Rainard, and B. Poutrel. 2000. Cells and cytokines in inflammatory secretions of bovine mammary gland. Adv. Exp. Med. Biol. 480:247-258.

Riollet, C., P. Rainard, and B. Poutrel. 2001. Cell subpopulations and cytokine expression in cow milk in response to chronic Staphylococcus aureus infection. J. Dairy Sci. 84:1077-1084.

Sanchez, M. S., C. W. Ford, and R. J. Yancey, Jr. 1994. Effect of tumor necrosis factor- $\alpha$, Interleukin- $1 \beta$, and antibiotics on the killing of intracellular Staphylococcus aureus. J. Dairy Sci. 77:1251-1258.

Sarikaya, H., C. Prgomet, M. W. Pfaffl, and R. M. Bruckmaier. 2004. Differentiation of leukocytes in bovine milk. Milchwissenschaft 59:586-589.

Sarikaya, H., and R. M. Bruckmaier. 2005. Importance of the sampled milk fraction for the prediction of total quarter milk SCC. Page 872 in Proc. 4th Int. IDF Mastitis Conf., Diagnosis of mastitis and indicators for milk quality. Maastricht, The Netherlands. Wageningen Acad. Publ., Wageningen, The Netherlands.

Schmitz, S., M. W. Pfaffl, H. H. D. Meyer, and R. M. Bruckmaier. 2004. Short-term changes of mRNA expression of various inflammatory factors and milk proteins in mammary tissue during LPS-induced mastitis. Domest. Anim. Endocrinol. 26:111-126.

Schukken, Y. H., K. E. Leslie, D. A. Barnum, B. A. Mallard, J. H. Lumsden, P. C. Dick, G. H. Vessie, and M. E. Kehrli. 1999. Experimental Staphylococcus aureus intramammary challenge in late lactation dairy cows: Quarter and cow effects determining the probability of infection. J. Dairy Sci. 82:2393-2401.

Schukken, Y. H., D. Van de Geer, F. J. Grommers, J. A. Smit, and A. Brand. 1989. Intramammary infections and risk factors for clinical mastitis in herds with low somatic cell counts in bulk milk. Vet. Rec. 125:393-396.

Sol, J., O. C. Sampimon, H. W. Barkema, and Y. H. Schukken. 2000. Factors associated with cure after therapy of clinical mastitis caused by Staphylococcus aureus. J. Dairy Sci. 83:278-284.

Sordillo, L. M., and K. L. Streicher. 2002. Mammary gland immunity and mastitis susceptibility. J. Mammary Gland Biol. Neoplasia 7:135-146.

Suriyasathaporn, W., Y. H. Schukken, M. Nielen, and A. Brand. 2000. Low somatic cell count: A risk factor for subsequent clinical mastitis in a dairy herd. J. Dairy Sci. 83:1248-1255.

Taylor, B. C., R. G. Keefe, J. D. Dellinger, Y. Nakamura, J. S. Cullor, and J. L. Stott. 1997. T cell populations and cytokine expression in milk derived from normal and bacteria-infected bovine mammary glands. Cell. Immunol. 1:68-76.

Wittmann, S. L., M. W. Pfaffl, H. H. D. Meyer, and R. M. Bruckmaier. 2002. 5-Lipoxygenase, cyclooxygenase-2 and tumor necrosis factor alpha gene expression in somatic milk cells. Milchwissenschaft 57:63-66.

Woolford, M. W., J. H. Williamson, and H. V. Henderson. 1998. Changes in electrical conductivity and somatic cell count between milk fraction from quarters subclinically infected with particular mastitis pathogens. J. Dairy Res. 65:187-198. 